\title{
Inhibition of lipopolysaccharide (LPS)- induced neuroinflammatory response by polysaccharide fractions of Khaya grandifoliola (C.D.C.) stem bark, Cryptolepis sanguinolenta (Lindl.) Schltr and Cymbopogon citratus Stapf leaves in raw 264.7 macrophages and U87 glioblastoma cells
}

Francine Kengne Mediesse1, Thaddée Boudjeko ${ }^{1,3^{*}}$, Anantharaju Hasitha², Matharasala Gangadhar², Wilfred Fon Mbacham ${ }^{3,4}$ and Perumal Yogeeswari ${ }^{2}$

\begin{abstract}
Background: Khaya grandifoliola (C.D.C.) stem bark, Cymbopogon citratus (Stapf) and Cryptolepis sanguinolenta (Lindl.) Schltr leaves are used in Cameroonian traditional medicine for the treatment of inflammatory diseases. Several studies have been performed on the biological activities of secondary metabolites extracted from these plants. However, to the best of our knowledge, the anti-neuro inflammatory and protective roles of the polysaccharides of these three plants have not yet been elucidated. This study aimed at investigating potential use of K. grandifoliola, C. sanguinolenta and C. citratus polysaccharides in the prevention of chronic inflammation.

Methods: Firstly, the composition of polysaccharide fractions isolated from K. grandifoliola stem bark (KGF), C. sanguinolenta (CSF) and C. citratus (CCF) leaves was assessed. Secondly, the cytotoxicity was evaluated on Raw 264.7 macrophages and U87-MG glioblastoma cell lines by the MTT assay. This was followed by the in vitro evaluation of the ability of KGF, CSF and CCF to inhibit lipopolysaccharides (LPS) induced overproduction of various pro-inflammatory mediators (NO, ROS and IL1 $\beta$, TNFa, IL6, NF-kB cytokines). This was done in Raw 264.7 and U87-MG cells. Finally, the in vitro protective effect of KGF, CSF and CCF against LPS-induced toxicity in the U87-MG cells was evaluated.

Results: CCF was shown to mostly contain sugar and no polyphenol while KGP and CSP contained very few amounts of these metabolites $(\leq 2 \%)$. The three polysaccharide fractions were non-toxic up to $100 \mu \mathrm{g} \cdot \mathrm{mL}^{-1}$. All the polysaccharides at $10 \mu \mathrm{g} / \mathrm{mL}$ inhibited NO production, but only KGF and CCF at $12.5 \mu \mathrm{g} / \mathrm{mL}$ down-regulated LPSinduced ROS overproduction. Finally, $100 \mu \mathrm{g} / \mathrm{mL}$ LPS reduced $50 \%$ of U87 cell viability, and pre-treatment with the three polysaccharides significantly increased the proliferation.

(Continued on next page)
\end{abstract}

\footnotetext{
* Correspondence: boudjeko@yahoo.com

'Laboratory of Phytoprotection and Valorisation of Plant Resources, The

Biotechnology Centre, University of Yaounde I, P.O. Box 3851,

Messa-Yaounde, Yaounde, Cameroon

${ }^{3}$ Department of Biochemistry, University of Yaounde I, P.O. Box 812, Yaounde,

Cameroon

Full list of author information is available at the end of the article
} 
(Continued from previous page)

Conclusion: These results suggest that the polysaccharides of K. grandifoliola, C. citratus and C. sanguinolenta could be beneficial in preventing/treating neurodegenerative diseases in which neuroinflammation is part of the pathophysiology.

Keywords: Plant polysaccharide, Khaya grandifoliola, Cryptolepis sanguinolenta, Cymbopogon citratus, Lipopolysaccharides, Anti-neuroinflammatory

\section{Background}

Lipopolysaccharides (LPS) derived from gram-negative bacteria are considered to be the most potent activators of the production of various inflammatory mediators such as pro and anti-inflammatory cytokines, nitric oxide (NO) by macrophages [1-3]. LPS excreted during bacterial infection cause chronic neuroinflammation and progressive neurodegeneration $[4,5]$, therefore their stimulation is a good model for mimicking neuroinflammatory conditions [6]. Abrogation of the inflammatory mediator's production may be the potential target(s) for neuroinflammatory therapeutics.

Children under the age of five affected by malaria are at risk of developing complications including severe anaemia and cerebral malaria (CM). CM occurs in non-immunized individuals and those with failure of standard antimalarial treatment [7]. It is mostly characterized by hyper-parasitemia, excessive production of pro-inflammatory cytokines (TNF $\alpha$, INF $\gamma$, IL1 $\beta$, IL6, IL12 etc.....) followed by up-regulation of endothelial cell adhesion molecule expression, which contribute to the sequestration of parasitized erythrocytes in the brain microvasculature [8]. This sequestration reduces the microvascular flow, thereby causing disruption of blood brain barrier (BBB), cerebral oedema and tissue hypoxia. Increasing evidence suggests that oxidative damage to cell components has a relevant pathophysiological role in several types of human diseases, including malaria. The inflammation of the brain may also contribute to a wide variety of neurodegenerative pathologies such as Alzheimer's and Parkinson's diseases, Amyotrophic Lateral Sclerosis, Multiples Sclerosis and psychiatric diseases $[9,10]$. A lot of anti-inflammatory drugs are commercialised but due to their potential secondary effects (teratogenic, mutagenic, cancerigenic, gastric, metabolic, endocrinal, neuronal disorders), it is necessary to discover and develop much safer and new bioactive compounds [11].

According to Xie et al. [12], there is an increasing interest of pharmaceutical sectors and researchers in polysaccharides isolated from medicinal plants because of their biological activities that are antioxidant (inhibition of lipid peroxidation, free radicals scavenging activities, protection of DNA from breaks induced by ROS), anti-inflammatory, anticancer [13-15], as well as the stimulation of PBMC proliferation and INFy cytokine production [16, 17]. Moreover, most polysaccharides derived from higher plants are relatively non-toxic and do not cause significant side effects as compared to immunomodulatory bacterial polysaccharides and synthetic compounds [18].

Khaya grandifoliola (Meliaceae family), Cryptolepis sanguinolenta (Periplocacees family) and Cymbopogon citratus (Poaceae family) are three medicinal plants found in Cameroon and many African countries. Decoctions from K. grandifoliola stem bark and root, $C$. sanguinolenta leaves and of $C$. citratus leaves are used in the treatment of malaria and other infectious diseases that provoke fever, pain and inflammation [19-21]. Numerous studies have been conducted in order to justify the folkloric use of these plants in the treatment of inflammatory diseases [11, 21-23]. The present work aimed at exploring the anti-neuroinflammatory (down-regulation of NO, ROS and various pro-inflammatory cytokines) of polysaccharide fractions isolated from these plants of interest. In vitro system experiment was performed using various spectrophotometry, cell biology and molecular biology techniques including: MTT assay, Griess reactions and DCFHDA assay, and Quantitative Real Time PCR.

\section{Methods \\ Materials}

The stem barks of Khaya grandifoliola C.D.C. (Welw) (Meliaceae family), leaves of Cymbopogon citratus Stapf (Poaceae family) and Cryptolepis sanguinolenta (Lindl.) Schltr (Periplocaceae family) were collected from Mbalmayo forest, Emana and Ongot respectively, in the Centre Region of Cameroon. The plant species were identified and authenticated by Mr. Nana of the National Herbarium of Cameroon, Yaounde (Cameroon), (Voucher specimen no: 52658/SFR-Cam, $\mathrm{N}^{\circ} 14,243 / \mathrm{HNC}$ and 28,247/SRFCam respectively for $K$. grandifoliola stem bark, C. citratus and C. sanguinolenta leaves).

\section{Polysaccharide fraction preparation}

The stem bark of $K$. grandifoliola, leaves of $C$. citratus and C. sanguinolenta were collected, shade-dried for one week at room temperature and powdered. Extraction of low molecular weight (LMW) polysaccharide fractions was performed as described by Thangam et al. [23] with slight modifications. Briefly, for the de-coloration and de-fatting process, $200 \mathrm{~g}$ of each powder was soaked in $60 \%$ methanol for $48 \mathrm{~h}$ in a shaker at $200 \mathrm{rpm}$. The resulting materials were boiled twice in $1 \mathrm{~L}$ of distilled water at $80{ }^{\circ} \mathrm{C}$ for $2 \mathrm{~h}$ and the 
supernatants were pooled and precipitated overnight at $4{ }^{\circ} \mathrm{C}$ with $95^{\circ}$ ethanol $(1: 2(v / v))$. The polysaccharides were collected by centrifugation, then dissolved in water and dialyzed against distilled water at room temperature. Each dialysate was then mixed with $4: 1(\mathrm{v} / \mathrm{v}) \mathrm{CH}_{2} \mathrm{Cl}_{2} / \mathrm{ButOH}$ solvent system and stirred for $15 \mathrm{~min}$. After centrifugation, the upper polysaccharide solution was collected and deproteinized twice with $\mathrm{CH}_{2} \mathrm{Cl}_{2} / \mathrm{ButOH}$ solvent until there were no proteins left. The absence of proteins in each fraction was confirmed by the Bradford (1976) [24] method. The deproteinized polysaccharide solutions were then subjected to lyophilization and LMW polysaccharide fractions were obtained and were named KGF, CSF and CCF for K. grandifoliola, C. sanguinolenta and C. citratus respectively.

\section{Quantification of total sugar and phenolic compounds}

Total sugars were determined using phenol- $\mathrm{H}_{2} \mathrm{SO}_{4}$ as described by Dubois et al. [25], where neutral monosaccharides were heated in acid medium and transformed into dehydrated derivatives of furfural. Practically, $0.2 \mathrm{~mL}$ of sample were mixed with $0.2 \mathrm{~mL}$ of $5 \%$ phenol. Then, $1 \mathrm{~mL}$ of concentrated sulfuric acid was added quickly and stirred. The mixture was placed at $100{ }^{\circ} \mathrm{C}$ for $10 \mathrm{~min}$ until it developed a yellow colour. The absorbance was read at $485 \mathrm{~nm}$. The amount and level of sugar present were calculated using glucose as standard and expressed as $\mu \mathrm{g}$ equivalent of glucose (GE) per mg of dry polysaccharides.

Phenolic compounds were estimated by the FolinCiocalteu method [15]. Briefly, $750 \mu \mathrm{L}$ of extract solution $(0.3 \mathrm{mg} / \mathrm{mL})$ of polysaccharide fractions were added to $75 \mu \mathrm{L}$ of Folin-Ciocalteu reagent. After $3 \mathrm{~min}, 750 \mu \mathrm{L}$ of $\mathrm{Na}_{2} \mathrm{CO}_{3}(20 \%)$ were added. The absorbance was measured at $760 \mathrm{~nm}$ using a UV-VIS 1605 Shimadzu spectrophotometer after $30 \mathrm{~min}$ in the dark. Phenolic compound amounts were calculated using ferulic acid as standard and expressed as $\mu \mathrm{g}$ equivalent of ferulic acid equivalent (FAE)/mg of dry polysaccharide.

\section{Toxicity of polysaccharide fractions on raw 264.7 macrophages and U87-MG cell lines}

RAW 264.7 cells, the murine macrophage cell line and the U87-MG human glioblastoma cell line were obtained from the National Centre for Cell Science (NCCS) Pune, India. RAW 264.7 cells and U87-MG cells were cultured respectively in RPMI 1640 medium and Minimum Essential Medium (MEM) supplemented with 10\% foetal bovine serum (FBS), L-Glutamine $(200 \mathrm{mM})$, streptomycin $(200 \mu \mathrm{g} / \mathrm{ml})$ and penicillin $(200 \mathrm{U} / \mathrm{ml})$ and maintained at $37{ }^{\circ} \mathrm{C}$ in an atmosphere of $5 \% \mathrm{CO}_{2}$. The assay was carried out on cells with $70 \%$ confluence. The cell viability was tested using Trypan Blue dye and at least $95 \%$ of viability was confirmed to carry out the assay.

RAW 264.7 cells $\left(1 \times 10^{5}\right)$ were treated with $10 \mu \mathrm{g} / \mathrm{mL}$ LPS with or without different concentrations of polysaccharide fractions $(100-1000 \mu \mathrm{g} / \mathrm{mL})$ for $24 \mathrm{~h}$ (polysaccharide samples were added $1 \mathrm{~h}$ before LPS). Non-treated cells were utilized as negative controls and cells treated with LPS alone were utilized as positive controls. Aspirin, a nonsteroid anti-inflammatory compound (previously shown to be non-toxic for Raw 264.7 cells), was used $1 \mu \mathrm{M}$ as positive control. After treatment, the cell culture supernatants were collected for nitrite assay and plated cells used for cell proliferation assessment by MTT assay.

Otherwise, U87-MG $\left(5 \times 10^{3}\right)$ cells were treated with different concentrations of polysaccharide fractions $(100-1000 \mu \mathrm{g} / \mathrm{mL})$ for $48 \mathrm{~h}$ and the cell proliferation was evaluated by MTT assay.

\section{Cell proliferation assay}

Proliferation of cells after treatment was determined by the 3-(4, 5-dimethylthiazol-2-yl)-2, 5-Diphenyltetrazolium Bromide (MTT) colorimetric assay [26]. After incubation, the medium was discarded, MTT $(0.5 \mathrm{mg} / \mathrm{mL}$ in PBS $1 \mathrm{X})$ was added to the treated cells and the plate was incubated for an additional $4 \mathrm{~h}$. The medium was discarded once more and Formazan Blue, which was formed in the cells, was dissolved with $100 \mu \mathrm{L}$ of Dimethylsulphoxide (DMSO). The optical density (OD) was measured at $590 \mathrm{~nm}$ against a background at $620 \mathrm{~nm}$ using a microplate reader (Molecular Device Spectra M4, USA). The cell viability was determined as (Mean A1 (590-620nm)/ Mean A0 $\left.{ }_{(590-620 \mathrm{~nm})}\right)^{*} 100$ where A0 and A1 are respectively the absorbance in untreated and treated wells. The toxicity or growth inhibitory percentage of polysaccharide fractions were determined by the formula: 1-[(Mean A1 (590-620nm) /Mean A0 (590-620nm) $)]^{*} 100$.

\section{In vitro evaluation of inhibitory effect of LPS-induced brain toxicity}

An U87-MG glioblastoma cell line was used in this assay to mimic in vitro brain toxicity. For optimization of LPS dose, U87 cells were treated with LPS $(1-200 \mu \mathrm{g} / \mathrm{mL})$ and growth inhibitory percentage determined by MTT assay as previously described. The inhibitory concentration 50 ( $\left.\mathrm{IC}_{50}\right)$ value was calculated using GraphPad Prism 6.01. The protective effect of polysaccharide fractions at non-toxic concentrations $(12.5-100 \mu \mathrm{g} / \mathrm{mL})$ on U87-MG was assessed by their co-incubation with LPS $(100 \mu \mathrm{g} / \mathrm{mL})$ for $48 \mathrm{~h}$ (polysaccharide samples were added $1 \mathrm{~h}$ before LPS). Diclofenac potassium at $50 \mu \mathrm{g} / \mathrm{mL}$ (previously shown to be non-toxic for U87-MG cells) was used as positive control. The medium was changed after $48 \mathrm{~h}$ and $100 \mu \mathrm{L}$ of MTT $(0.5 \mathrm{mg} / \mathrm{ml}$ stock solution) were added and the plates incubated for an additional $4 \mathrm{~h}$. The medium was once more discarded and the Formazan Blue insoluble crystal, which was formed in the cells, was dissolved with $100 \mu \mathrm{L}$ of DMSO. The OD was measured at $590 \mathrm{~nm}$ against a 
background at $620 \mathrm{~nm}$. The protective effect of KGF, CSF and CCF was evaluated using GraphPad Prism 6.01.

\section{Nitrite assay}

After treatment of RAW 264.7 cells with/without nontoxic concentrations of polysaccharide fractions and LPS, cell culture supernatant was used to quantify the NO secretion by the measurement of nitrite concentration in the supernatants using the Griess reaction [27]. Each culture supernatant was mixed with the same volume of Griess reagent $1 \mathrm{X}$ and the absorbance of the mixture at $540 \mathrm{~nm}$ was determined with a microplate reader (Molecular Device Spectra M4, USA). Fresh RPMI culture medium was used as the blank and the amount of nitrite in the samples was measured with the sodium nitrite serial dilution standard curve.

\section{Intracellular reactive oxygen species (iROS) estimation} Intracellular ROS estimation was measured using DCFH-DA [28]. Approximately $5 \times 10^{3}$ U87-MG cells/ well were plated on 96-well plates and treated with various polysaccharide fractions and/or LPS $10 \mu \mathrm{g} / \mathrm{mL}$ for $24 \mathrm{~h}$. Then, the plates were washed with PBS 1X cells were treated with $10 \mu \mathrm{M}$ DCFH-DA for $1 \mathrm{~h}$. The loading buffer was removed and the plates washed. New PBS 1X was added into each well and oxidized DCFH excitation and emission were measured at 485 and $525 \mathrm{~nm}$ respectively in a spectrophotometer (SpectraMax M4, Molecular Devices, Sunnyvale, USA). Diclofenac potassium at non-toxic concentration on U87-MG was used as positive control. Percentage ROS production inhibition was computed using Graph Pad prism 6.01.

\section{In vitro evaluation of inhibitory effect of LPS-induced overexpression of pro-inflammatory cytokines}

About $10^{5} \mathrm{U} 87-\mathrm{MG}$ cells/well/2 mL in 96 well plates were treated with polysaccharide fractions for $1 \mathrm{~h}$ followed by $100 \mu \mathrm{g} / \mathrm{mL}$ LPS for $48 \mathrm{~h}$. After incubation, cells were washed with $500 \mu \mathrm{L}$ of PBS $1 \mathrm{X}$, and total RNA was extracted from the untreated cells and from the LPS and/or polysaccharide fraction treated cells using RNA Xpress reagent according to the manufacturer's protocol. RNA was then quantified with Nanodrop and purity of RNA was determined with $\mathrm{A}_{260} / \mathrm{A}_{280}$ ratio (1.8-2.0 was considered pure). RNA $(1 \mu \mathrm{g})$ was reverse-transcribed using a cDNA synthesis kit. Quantitative Real Time PCR was performed on reversed-transcribed cDNA products for determination of TNF- $\alpha$, IL6, IL-1 $\beta$ and NF-kB expression according to the manufacturer's instructions using a BIO-RAD CFX Connect, with SYBR Green (Kapa Biosystems) as the fluorescent dye, enabling real-time detection of PCR products. Sense and antisense PCR primers used in this study were purchased from Sigma Genosis, India (Table 1). All samples were run in triplicates and the output values reported were the average of three wells. The amplification consisted of denaturation at $95^{\circ} \mathrm{C}$ for $25 \mathrm{~s}$, primer annealing at $58-64{ }^{\circ} \mathrm{C}$ for $30 \mathrm{~s}$ and extension at $72{ }^{\circ} \mathrm{C}$ for $1 \mathrm{~min}$, for a total of 37 cycles followed by final extension at $72{ }^{\circ} \mathrm{C}$ for $10 \mathrm{~min}$. For quantification, the target gene was normalized to the internal standard GAPDH gene.

\section{Statistical analysis}

Results were expressed as the means \pm SEM. Multi group comparison was performed by one-way analysis of variance, followed by the Dunnet's multiple comparisons as a post hoc analysis test for comparison between polysaccharide treatment and positive control, non-treated or LPS group at $p<0.05, p<0.01$ and $p<0.001$. Calculations were performed using GraphPad InStat version 6.01 software. $\mathrm{IC}_{50}$ was analyzed using non-linear regression.

\section{Results}

Partial composition and in vitro toxicity of polysaccharide fractions

After the extraction procedure that included deproteinization, carbohydrates were the major components in the polysaccharide fractions. C. citratus polysaccharide presents the highest level of sugar $(629.78 \pm$ $1.4 \mu \mathrm{g} \mathrm{GE} / \mathrm{mg}$ of dry polysaccharide) and no polyphenols. However, small amount of polyphenols were found in KGF and CSF polysaccharides (less than 2\%) (Table 2). Therefore, the potential of these polysaccharide fractions could be related only to their carbohydrate content.

In order to assess the effects of all the three polysaccharide fractions on the viability of RAW 264.7 and U87-MG cells, the cells were treated with the indicated concentrations of KGF, CSF and CCF in the presence or absence of LPS and cell viability analysed by MTT assay. The results were shown in Fig. 1. The viability of RAW 264.7 cells was not significantly altered after $24 \mathrm{~h}$ of incubation with up to $100 \mu \mathrm{g} / \mathrm{ml}$ of polysaccharide fractions (Fig. 1) and the data revealed noticeable toxicity on U87 MG for all the fractions tested with less than $100 \mu \mathrm{g} / \mathrm{mL}$ for $48 \mathrm{~h}(p$ $<0.001)$. Up to $100 \mu \mathrm{g} / \mathrm{mL}$, all the polysaccharide fractions significantly altered the two cells viability in a dosedependent manner and cell viability decreased with increasing concentration. A growth inhibitory concentration of $80 \%$ was observed at $1 \mathrm{mg} / \mathrm{mL}$. The results of the $\mathrm{IC}_{50}$ concentrations for RAW 264.7 and U87-MG cells with respect to all the three fractions are shown in Table 3. Therefore, in subsequent experiments, the concentrations of polysaccharide fractions used were 10 to $100 \mu \mathrm{g} / \mathrm{mL}$.

\section{Effect of KGF, CSF and CCF in LPS induced anti-proliferation in the U87-MG cell lines}

The protective effect of KGF, CSF and CCF over LPS induced toxicity was evaluated through MTT assay. The protective effect of polysaccharide fractions is their ability to 
Table 1 Details of primer sequences (Sigma Genosys) used for inflammatory mediators gene expression through RT-PCR amplification

\begin{tabular}{|c|c|c|c|c|}
\hline Genes & Oligoname & $\begin{array}{l}\text { Oligonucleotide sequence } \\
5^{\prime} \ldots \ldots \ldots \ldots \ldots \ldots \ldots \ldots \ldots \ldots \ldots \ldots \\
\end{array}$ & Length & Anneal $\mathrm{T}^{\circ}$ \\
\hline \multirow[t]{2}{*}{ IL6 } & Human-IL6-FP & TTCGGTCCAGTTGCCTTCTC & 20 & $61.8^{\circ} \mathrm{C}$ \\
\hline & Human-IL6-RP & GAGGTGAGTGGCTGTCTGTG & 20 & \\
\hline \multirow[t]{2}{*}{ TNFa } & Human-TNFalpha-FP & CTCCAGGCGGTGCCTTGTTC & 20 & $60.4^{\circ} \mathrm{C}$ \\
\hline & H-TNFalpha-RP & CAGGCAGAAGAGCGTGGTG & 19 & \\
\hline \multirow[t]{2}{*}{ IL1 $\beta$} & Human-IL1 beta-FP & GCAAGGGCTTCAGGCAGGCCGCG & 23 & $64^{\circ} \mathrm{C}$ \\
\hline & Human-IL1 beta-RP & GGTCATTCTCCTGGAAGGTCTGTGGGC & 27 & \\
\hline \multirow[t]{2}{*}{$N F-k B$} & Human-Nf-kB-FP & GCGCTTCTCTGCCTTCCTTA & 20 & $58^{\circ} \mathrm{C}$ \\
\hline & Human-Nf-kB-RP & TCTTCAGGTTTGATGCCCCC & 20 & \\
\hline \multirow[t]{2}{*}{ GAPDH } & Human-GAPDH-FP & ACCACAGTCCATGCCATCAC & 20 & $60.4^{\circ} \mathrm{C}$ \\
\hline & Human-GAPDH-RP & TCCACCACCCTGTTGCTGT & 19 & \\
\hline
\end{tabular}

inhibit LPS toxicity and increase U87-MG cell proliferation. The $\mathrm{IC}_{50}$ for LPS in the U87-MG was found to be $100 \mu \mathrm{g} / \mathrm{mL}$. LPS $(100 \mu \mathrm{g} / \mathrm{mL})$ treatment significantly decreased cell viability from 100 to $52.3 \pm 3.1 \%$ but polysaccharides co-treatment increased the U87-MG proliferation and viability $(p<0.001)$. According to the concentrations of the test fractions, KGF and CCF were most active at $12.5 \mu \mathrm{g} / \mathrm{mL}$ (cell viability up to $83.3 \pm 0.2$ and $72.9 \pm 0.8 \%$ respectively) (Fig. 2). The protective effect of CSF was observed at $50 \mu \mathrm{g} / \mathrm{mL}$ (cell viability up to $65.21 \pm 0.72 \%$ ). However, no dose-dependent linear effect was observed. Compared to polysaccharides, diclofenac potassium at $50 \mu \mathrm{g} / \mathrm{mL}$ was non-toxic on U87-MG cells $(4.8 \pm 0.8 \%$ of growth inhibitory percentage) and presented the best protective effect (cell viability up to $99.97 \pm 0.03 \%)(p<0.001)$.

\section{Effect of KGF, CSF and CCF on NO and ROS secretion}

To investigate whether polysaccharide fractions regulate NO production, RAW 264.7 cells were pretreated with KGF, CSF and CCF for $1 \mathrm{~h}$ before treatment with LPS for $24 \mathrm{~h}$, and nitrite content, a stable end product of $\mathrm{NO}$ was measured using Griess reaction. Treatment with LPS resulted in significant up-regulation of nitrite production $(7.05 \pm 0.09 \mu \mathrm{M})$, compared to the untreated control $(3.5 \pm 0.3 \mu \mathrm{M})$ (Fig. 3). However, RAW 264.7 cells pretreated with all the polysaccharide fractions at $100 \mu \mathrm{g} / \mathrm{mL}$ displayed a marked decrease in the induction

Table 2 Total sugar and polyphenols content of polysaccharides fractions of Khaya grandifoliola stem bark (KGF), Cryptolepis sanguinolenta (CSF) and Cymbopogon citratus (CCF) leaves by Phenol-sulfuric and Folin-Ciocalteu methods (mean \pm SEM; $n=3$ )

\begin{tabular}{lll}
\hline Polysaccharide fractions & $\begin{array}{l}\text { Total sugar } \\
\text { content }(\mu \mathrm{g} \mathrm{GE} / \mathrm{mg})\end{array}$ & $\begin{array}{l}\text { Total polyphenol } \\
(\mu \mathrm{g} \mathrm{FAE} / \mathrm{mg})\end{array}$ \\
\hline KGF & $450.09 \pm 0.33$ & $17.76 \pm 0.15$ \\
$\mathrm{CSF}$ & $437.19 \pm 0.53$ & $15.54 \pm 0.5$ \\
CCF & $629.78 \pm 1.39$ & 0 \\
\hline
\end{tabular}

of nitrite after stimulation with LPS $(p<0.001)$. The nitrite production were respectively $2.56 \pm 0.25 ; 3.02 \pm 0.09$ and $2.8 \pm 0.16 \mu \mathrm{M}$ for KGF, CSF and CCF treated cells at $100 \mu \mathrm{g} / \mathrm{mL}$. The growth inhibitory percentage of Aspirin at $1 \mu \mathrm{M}(180 \mu \mathrm{g} / \mathrm{mL})$ on Raw 264.7 cells was $0.98 \pm$ $0.28 \%$. At this concentration, Aspirin-treated cells produced $2.46 \pm 0.1 \mu \mathrm{M}$ of nitrite. On the other hand, estimation of intracellular ROS was performed using DCFH-DA. The U87-MG cell treated with $10 \mu \mathrm{g} / \mathrm{mL}$ of LPS showed increased DCF fluorescence levels

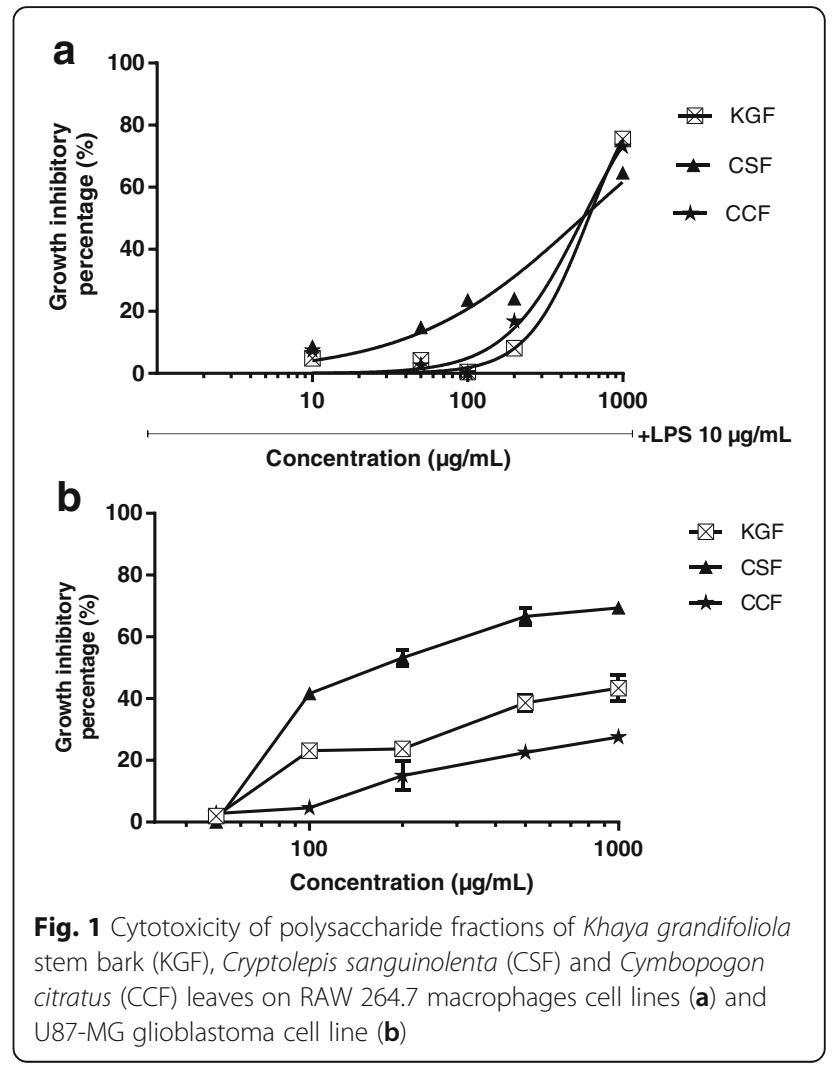


Table 3 Inhibitory concentration 50 for Raw 264.7 Macrophages and U87-MG Glioblastoma cells line with respect to polysaccharide fractions of $K$. grandifoliola stem bark, C. sanguinolenta and C. citratus leaves

\begin{tabular}{lll}
\hline Polysaccharide fractions & $\begin{array}{l}\mid \mathrm{IC50}(\mu \mathrm{g} / \mathrm{mL}) \\
\text { for Raw 264.7 cells }\end{array}$ & $\begin{array}{l}\mid \mathrm{IC50}(\mu \mathrm{g} / \mathrm{mL}) \\
\text { for U87-MG }\end{array}$ \\
\hline KGF & 600.9 & $>1000$ \\
CSF & 545 & 243.7 \\
CCF & 554.1 & $>1000$ \\
\hline
\end{tabular}

(compared to the control, $P<0.005$ ) indicating of intracellular ROS production (Fig. 4). However, preincubation with KGF and CCF polysaccharide $(12.5 \mu \mathrm{g} /$ $\mathrm{mL})$ and Diclofenac potassium $(50 \mu \mathrm{g} / \mathrm{mL})$ for $1 \mathrm{~h}$ before LPS treatment decreased the fluorescence intensity of the cells. CSF polysaccharide did not reduce intracellular ROS in LPS-induced U87-MG. The most promising KGF and

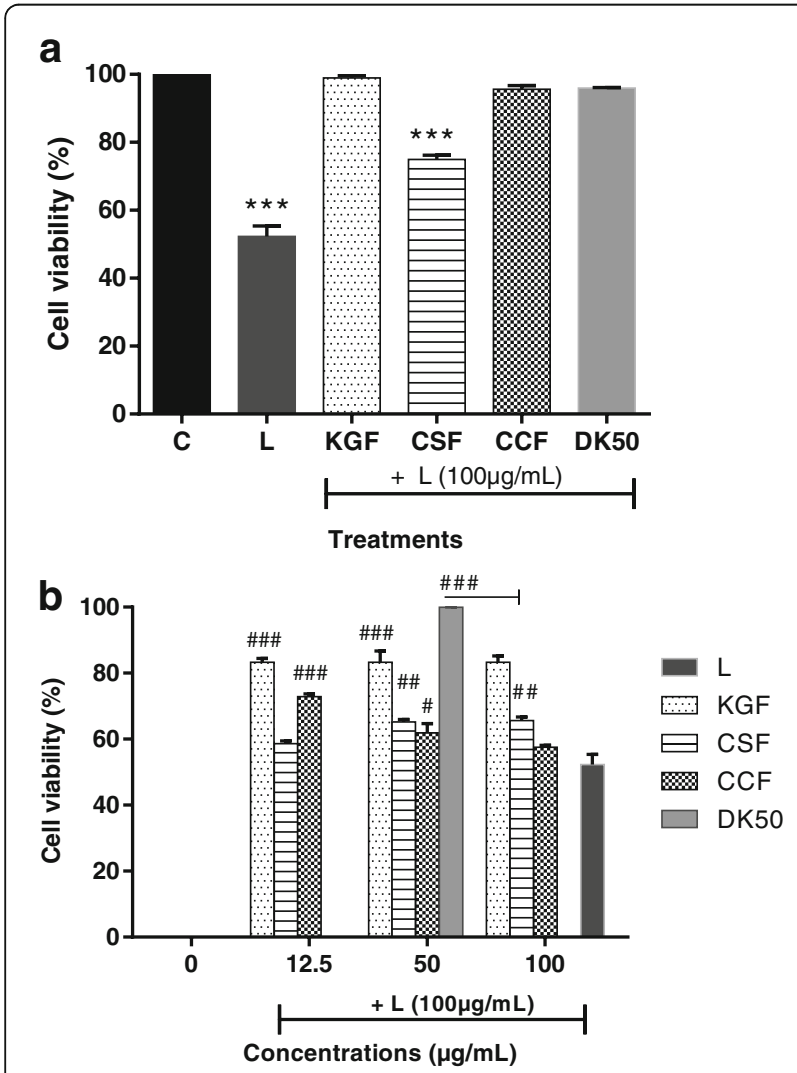

Fig. 2 Inhibition of LPS toxicity on U87 cell lines by various polysaccharide fractions and diclofenac potassium; (a) C-control cells; L-LPS (100 g/mL), KGF, CSF, CCF polysaccharides of Khaya grandifoliola stem bark, Cryptolepis sanguinolenta and Cymbopogon citratus leaves were tested at $100 \mu \mathrm{g} / \mathrm{mL}$ and Diclofenac potassium at $50 \mu \mathrm{g} / \mathrm{mL}$ (DK50). Data are expressed as mean $\pm \mathrm{SEM},{ }^{* * *}$ denote statistical significance $p<0.001$ in comparison to the control group; (b) KGF, CSF, CCF polysaccharides were tested at 12.5, 50 and $100 \mu \mathrm{g} / \mathrm{mL}$ and DK50 \#, \#\#, \#\#\# denote statistical significance at $p<0.05, p<0.01 \& p<0.001$ in comparison to the LPS treated group

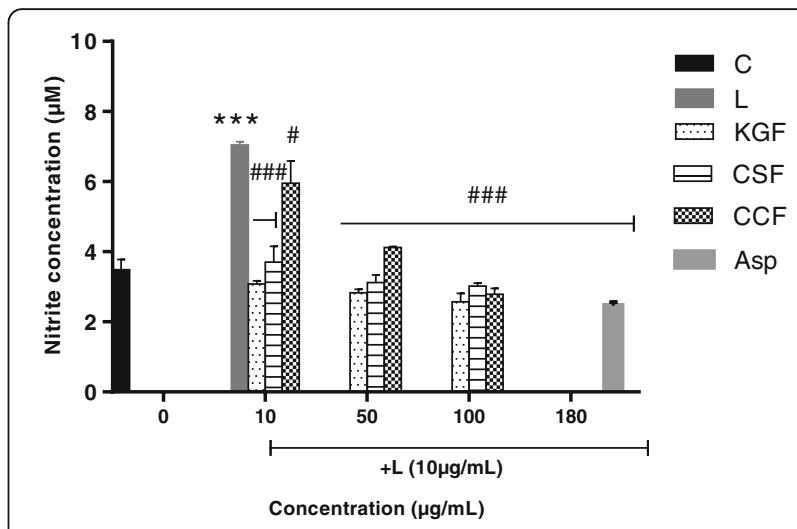

Fig. 3 Effects of polysaccharides fractions of Khaya grandifoliola stem bark (KGF), Cryptolepis sanguinolenta (CSF) and Cymbopogon citratus (CCF) leaves and Aspirin (Asp) on the secretion of NO by LPS-stimulated RAW 264.7 macrophages cells. C-Non-treated cells; L-LPS $(10 \mu \mathrm{g} / \mathrm{mL})$ treated cells, Asp-Aspirin $1 \mu \mathrm{M}(180 \mu \mathrm{g} / \mathrm{mL})$ treated cells, Data expressed as mean \pm SEM $(n=3) .{ }^{*},{ }^{* *},{ }^{* * *}$ denote statistical significance at $p<0.05, p<0.01 \& p<$ 0.001 in comparison to the control group. \#, \#\#, \#\#\# denote statistical significance at $p<0.05, p<0.01 \& p<0.001$ in comparison to the LPS treated group (Dunnet multiple comparison, graph Pad Prism 6.0)

CSF showed the best NO and ROS inhibitory effects in LPS stimulated RAW 264.7 and U87-MG cell lines.

\section{Effect of polysaccharide fractions on mRNA expression of IL-1 $\beta$, IL6, NF-kB and TNFa}

The systematic study of simultaneous changes in gene expression for several pro-inflammatory cytokines in

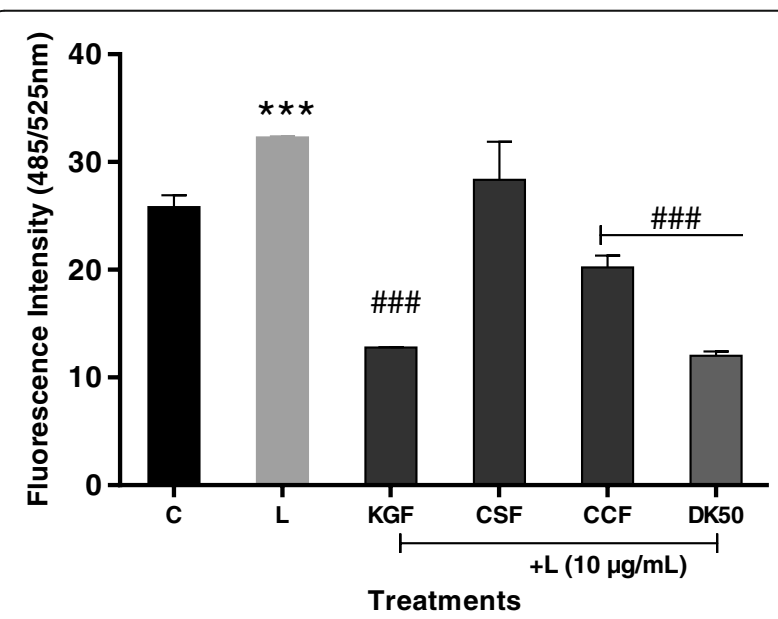

Fig. 4 Effects of polysaccharides isolate from Khaya grandifoliola stem bark (KGF), Cryptolepis sanguinolenta (CSF) and Cymbopogon citratus (CCF) leaves at $12.5 \mu \mathrm{g} / \mathrm{mL}$ and Diclofenac potassium on the secretion of ROS by LPS-stimulated U87-MG cells. C-control cells; L-LPS $(10 \mu \mathrm{g} / \mathrm{ml})$, DK50-Diclofenac potassium $50 \mu \mathrm{g} / \mathrm{mL}$. Data expressed as mean \pm SEM $(n=3) .{ }^{*}, * *, * * *$ denote statistical significance at $p<0.05, p<0.01 \& p<0.001$ in comparison to the control group. \#, \#\#, \#\#\# denote statistical significance at $p<0.05$, $p<0.01 \& p<0.001$ in comparison to the LPS treated group (Dunnet multiple comparaison, graph Pad Prism 6.0) 
LPS-induced U87-MG cell lines was performed using Real Time gene expression studies. Comparing the LPStreated and untreated cells, IL- $1 \beta, N F-k B$, and TNF- $\alpha$ expression showed significant up-regulation. KGF and CCF polysaccharides at $12.5 \mu \mathrm{g} / \mathrm{mL}$ were able to significantly reduce the over-expressions of IL-6, IL-1 $\beta$, NF-kB but only CCF reduced TNF- $\alpha$ over-expression. KGF and CCF suppressed the production of IL- 6 and IL- $1 \beta$ in LPS-induced U87-MG cell lines by inhibiting NF- $к B$ activation which is an important signaling pathway involved in the production of cytokines. Diclofenac potassium at $50 \mu \mathrm{g} / \mathrm{mL}$ was more active on $\mathrm{IL}-1 \beta$ and NF-kB compared to the polysaccharides (Fig. 5).

\section{Discussion}

Polysaccharides are present in plants, animals and microorganisms bound to with proteins and phenolic compounds. During their extraction, these others compounds are also obtained in various concentrations. Phenolic compounds are known to have several biological activities including antioxidant and anti-inflammatory properties [29]. According to Chen et al. [30] and Mediesse et al. [15], the bioactivity of polysaccharide extracts increases in a dose-dependent manner with protein, phenolic and lipid contents. Recent studies now show that pure polysaccharides also have several biological activities [23, 31]. Some research has been oriented towards the identification of pure and bioactive polysaccharides. In this study, the modulation of $K$ grandifoliola, C. sanguinolenta and C. citratus polysaccharide fractions for LPS-induced inflammatory responses were examined in vitro. From cytotoxicity experiments, it was observed that the CSF polysaccharide exhibited more significant cytotoxic effect against the cancer cells than KGF and CCF fractions. The concentrations of KGF, CSF and CCF polysaccharides $(\leq 100 \mu \mathrm{g} / \mathrm{mL})$ used in this study were considered to be non-cytotoxic.

During inflammation, macrophages induce the expression of pro-inflammatory genes such as inducible nitric

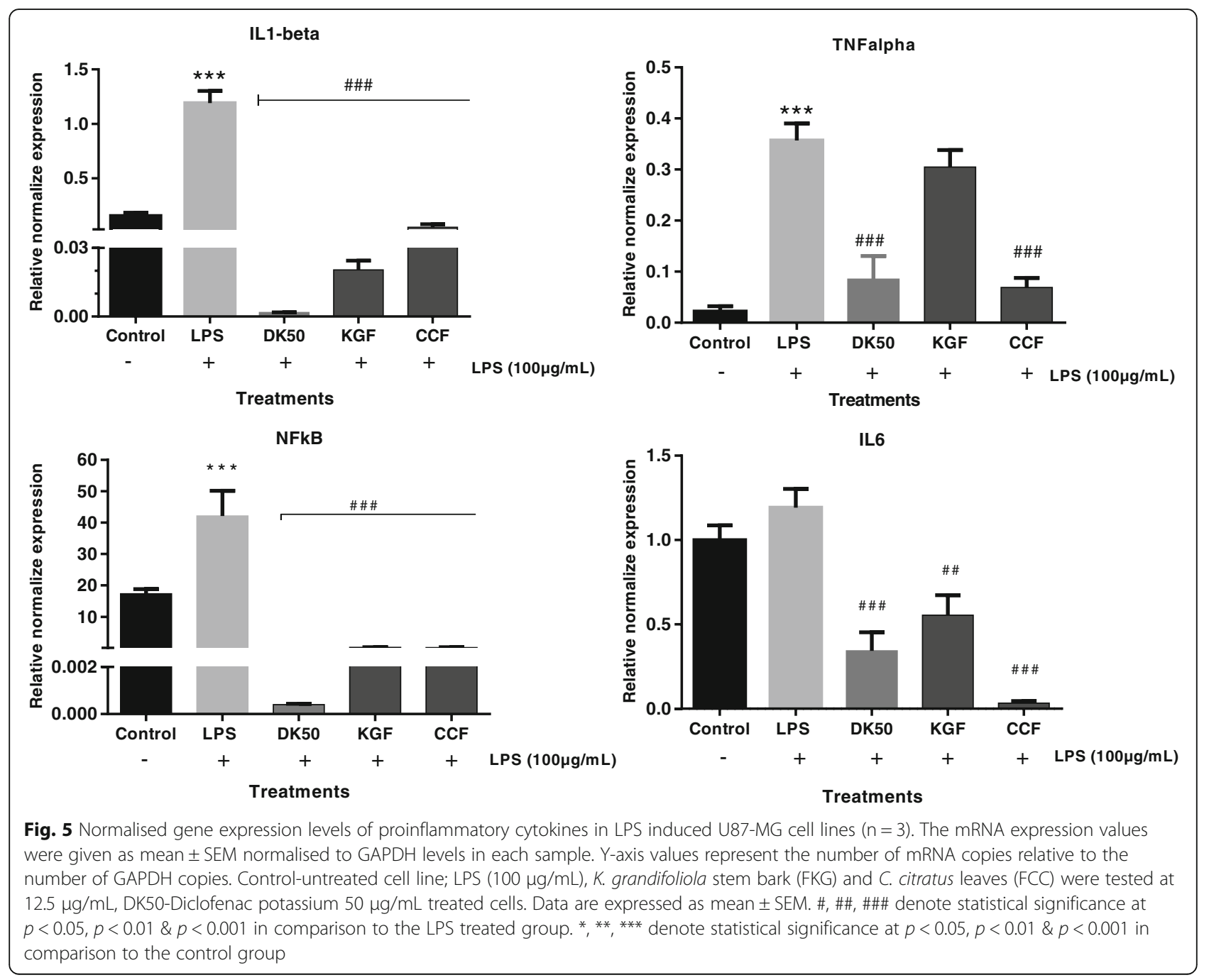


oxide synthase (iNOS). Cytokines, such as interleukin (IL)1, IL-6, and tumor necrosis factor (TNF), have been known to play important roles in pro-inflammatory response $[32,33]$; and iNOS is up-regulated by secretion of pro inflammatory cytokines and produces nitric oxide from Larginine. Because high concentrations of NO can be toxic, the regulation of $\mathrm{NO}$ production is therefore an important target for inflammatory disease [34]. Our results indicate that FKG, FCS and FCC treatment can reduce NO in the RAW 264.7 cell. Pacheco-sanchez et al. [35] also reported that polysaccharides extracted from Collybia dryophila treatment showed a down-regulation effect of $\mathrm{NO}$ production. According to Kim et al. [36] classification, the percentage of $\mathrm{NO}$ inhibition from plant extract represents its anti-inflammatory potential. Therefore KGF and CCF polysaccharides could be considered as moderate and CSF polysaccharide as weak anti-inflammatory agent. In addition, LPS stimulates various transcription factors especially NF- $\mathrm{kB}$ which causes a chain of mechanisms, resulting in the production of pro-inflammatory cytokines TNF $\alpha$, IL1 $\beta$, and IL6 and inflammatory mediator iNOS $[37,38]$. Persistent NF- $\mathrm{kB}$ activation also causes chronic inflammation, which has long been related to certain types of cancers $[39,40]$. In this study, after LPS incubation with U87 glioblastoma cell, the pro-inflammatory cytokine TNF $\alpha$, IL1 $\beta$, and IL6 levels were elevated; the response was reversed by co-incubation of polysaccharide fractions in LPS. Several studies suggested that the biological activities of polysaccharides would strongly depend on their monosaccharide composition, structure, the degree of sulfation, the molecular weight, the sulfation pattern, and the glycosidic branches [41]. Luhm et al. [42] reported that $\beta(1 \rightarrow 3)$-DGlucans from plant material were shown to be capable of having beneficial effects in pre-inflammatory responses, indicating that $\beta$-glucan can be a modulator of the antiinflammatory response as interleukin mediators. We do not exactly understand the mechanism by which the KGF, CSF and CCF treatment reduce inflammation in the RAW 264.7 and U87 cells. Therefore, more research is needed to understand the effects of treatment with $K$. grandifoliola, C. sanguinolenta and C. citratus polysaccharide fractions on anti-inflammation and how these three polysaccharide fractions relate to changes of cytokine, ROS and NO.

\section{Conclusion}

The present study was conducted to explore the potential use of $K$. grandifoliola, $C$. sanguinolenta and C. citratus polysaccharides to prevent chronic neuroinflammation. The results of the study show that KGF, CSF and CCF inhibit the toxic effect of LPS, increase brain cell (U87-MG) proliferation and exert anti-inflammatory effect by regulating various pro-inflammatory mediators (NO, ROS and pro-inflammatory cytokines). However, further detailed experiments need to be performed to understand the exact mechanisms by which they act. Thus, KGF and CCF particularly present the best activities which could be used in a variety of painful conditions and also to attenuate neuroinflammation in neurological disorders.

\begin{abstract}
Abbreviations
CNS: Central Nervous System; DCFH-DA: Dichlorofluorescein diacetate; FCC: Polysaccharide fraction of Cymbopogon citratus; FCS: Polysaccharide fraction of Cryptolepis sanguinolenta; FKG: Polysaccharide fraction of Khaya grandifoliola; GAPDH: Glyceraldehyde phosphate dehydrogenase; INFY: Interferon gamma; iROS: intracellular reactive oxygen; LPS: Lipopolysaccharide; MEM: Minimum Essential Medium; MTT: 3-(4,5dimethylthiazol-2-yl)-2,5-diphenyltetrazolium bromide; NF-kB: Nuclear factor kappa B; NO: Nitrite oxide; TNFa: Tumor Necrosis Factor a
\end{abstract}

\section{Acknowledgments}

The authors thank M. Nana of the Cameroon National Herbarium for plants identification. The authors are grateful to Professor Atogho-Tiedeu Barbara (Department of Biochemistry, University of Yaounde 1, Cameroon) for improving the English text.

\section{Funding}

We gratefully acknowledge the Centre for Science and Technology of the NonAligned and Other Developing Countries (NAM S\&T Centre) for providing the fellowship (Research Training Fellowship for Developing Country Scientist, RTF-DCS 14-15) at BITS, Pilani (India) to one of the authors Mediesse Kengne Francine.

Availability of data and materials

All data are contained and described within the manuscript. The datasets used and/or analysed during the current study are available from the corresponding author on reasonable request.

\section{Authors' contributions \\ TB, WFM and PY conceived the project, designed the study and were involved in the drafting and correction of the manuscript. TB and PY also coordinated the study. FMK carried out extraction of polysaccharides, oxidative and immunomodulatory assays, analysis and interpretation of data and participated in the correction of the manuscript. AH and MG participated in the work design and drafting of manuscript. All authors read and approved the final manuscript.}

Ethics approval and consent to participate

Not applicable.

Consent for publication

All authors gave their consent for the publication of the manuscript.

\section{Competing interests}

The authors declare that they have no competing interests.

\section{Publisher's Note}

Springer Nature remains neutral with regard to jurisdictional claims in published maps and institutional affiliations.

\section{Author details}

${ }^{1}$ Laboratory of Phytoprotection and Valorisation of Plant Resources, The Biotechnology Centre, University of Yaounde I, P.O. Box 3851,

Messa-Yaounde, Yaounde, Cameroon. ${ }^{2}$ Drug Discovery Research Laboratory, Department of Pharmacy, Birla Institute of Technology and Science-Pilani, Hyderabad campus, Jawahar Nagar, Hyderabad, Andhra Pradesh -500078, India. ${ }^{3}$ Department of Biochemistry, University of Yaounde I, P.O. Box 812 Yaounde, Cameroon. ${ }^{4}$ Laboratory of Public Health Research Biotechnologies, The Biotechnology Centre, University of Yaounde I, P.O. Box 3851 ,

Messa-Yaounde, Yaounde, Cameroon. 
Received: 12 October 2017 Accepted: 2 March 2018

Published online: 12 March 2018

\section{References}

1. Lee YL, Han JY, Lee CG, Heo K, Park SI, Park YS, Kim JS, Yang KM, Lee KJ, Kim $\mathrm{TH}$, Rhee $\mathrm{MH}$, Kim SD. Korean red ginseng saponin fraction modulates radiation effects on lipopolysaccharide-stimulated nitric oxide production in RAW264.7 macrophage cells. J Ginseng Res. 2014;38:208-14.

2. Holden JA, Attard TJ, Laughton KM, Mansell A, O'Brien-Simpson NM Reynolds EC. Porphyromonas gingivalis lipopolysaccharide weakly activates M1 and M2 polarized mouse macrophages but induces inflammatory cytokines. Inf Immu. 2014;82(10):4190-203.

3. Pallai A, Kiss B, Vereb G, Armaka M, Kollias G, Szekanecz Z, Szondy Z Transmembrane TNF-a reverse signaling inhibits lipopolysaccharide-induced proinflammatory cytokine formation in macrophages by inducing TGF- $\beta$ : therapeutic implications. J Immunol. 2016;196:1146-57.

4. Liya Q, Wu X, Block ML, Liu Y, Breese GR, Hong JS, Knapp DJ, Crews FT. Systemic LPS causes chronic neuroinflammation and progressive neurodegeneration. NIH Pub Acc. 2007:55:453-62.

5. Pizza V, Agressa A, D'Acunto CW, Festa M, Capasso A. Neuroinflamm-ageing and neurodegenerative diseases: an overview. CNS Neurol Disord Drug Target. 2011;10:621-34

6. Niranjan R, Kamat PK, Nath C, Shukla R. Evaluation of guggulipid and nimesulide on production of inflammatory mediators and GFAP expression in LPS stimulated rat astrocytoma, cell line (C6). J Ethnopharmacol. 2010;127:625-30.

7. Dondorp AM, Day NPJ. The treatment of severe malaria. Trans Roy Soc Trop Med Hyg. 2007;101(7):633-4.

8. Schofield L, Grau GE. Immunological processes in malaria pathogenesis. Immunol. 2005;5:722-35.

9. Reynolds A, Laurie C, Lee MR, Gendelman HE. Oxidative stress and the pathogenesis of neurodegenerative disorders. Inter Rev Neurobiol. 2007;82: 297-325.

10. Koppula S, Kumar H, Kim IS, Choi DK. Reactive oxygen species and inhibitors of inflammatory enzymes, NADPH oxidase, and iNOS in experimental models of Parkinson's disease. Mediators Inflamma. 2012; https://doi.org/10. 1155/2012/823902

11. Guidetti G, Di Cerbo A, Giovazzino A, Rubino V, Palatucci AT, Centenaro S, Fraccaroli E, Cortese L, Bonomo MG, Ruggiero G, Canello S, Terrazzano G. In vitro effects of some botanicals with anti-inflammatory and antitoxic activity. J Immunol Res. 2016;2016:5457010.

12. Xie JH, Jin ML, Morris GA, Zha XQ, Chen HQ, Yi Y, Li JE, Wang ZJ, Gao J, Nie SP, Peng S, Xie MY. Advances on bioactive polysaccharides from medicinal plants. Crit Rev Food Sci Nutr. 2015; https://doi.org/10.1080/10408398.2015. 1069255.

13. Xiaojuan $\mathrm{H}$, Xuyan $\mathrm{N}$, Jian L, Shaohua X, Aiping L. Immunomodulatory activities of five clinically used Chinese herbal polysaccharides: A Review. J Experimen Integr Med. 2012;2:15-27.

14. Amit G, Pallavi RK, Sushama C. Applications and Uses of active ingredients from medicinal plants. Indi J Nov Drug Deliv. 2014;6:106-11.

15. Mediesse KF, Woguia AL, Fogue SP, Atogho TB, Simo G, Boudjeko T. Antioxidant properties of cell wall polysaccharides of Stevia rebaudiana leaves. J Coast Life Med. 2014;2:962-9.

16. Aboughe-Angone S, Nguema-Ona E, Boudjeko T, Driouich A. Plant cell wall polysaccharides as immmunomodulators of the immune system. Cur Top Phytochemistry. 2011;10:1-16.

17. Boudjeko T, Megneko R, Woguia AL, Mediesse KF, WEJ K, Nounga TCD, Koum O. Antioxidant and Immunomodulatory properties of cell wall polysaccharides isolated from Allanblackia floribunda Oliv stem bark and Chromolaena odorata (L) king and H.E. Robins leaves. BMC Res Notes. 2015;8:759.

18. Schepetkin IA, Quinn MT. Botanical polysaccharides: macrophage immunomodulation and therapeutic potential. Int Immunopharmacol. 2006; 6:317-33.

19. Njayou FN, Aboudi ECE, Tandjang MK, Tchana AK, Ngadjui BT, Moundipa PF. Hepatoprotective and Antioxidant activities of stem bark extract of Khaya grandifoliola (Welw) CDC and Entada africana Guill. Et Perr. J Nat Prod. 2013;6:73-80.

20. Ravinder K, Pawan K, Gaurav S, Paramjot K, Gagan S, Appramdeep K. Pharmacognostical investigation of Cymbopogon citratus (DC) Stapf. Der Pharma Let. 2010;2:181-9.

21. Tempesta MS. The clinical efficacy of Cryptolepis sanguinolenta in the treatment of malaria. Ghana Med J. 2010;44:1-2.
22. Tiwari M, Dwivedi UN, Kakkar P. Suppression of oxidative stress and proinflammatory mediators by Cymbopogon citratus D. Stapf extract in lipopolysaccharide stimulated murine alveolar macrophages. Food Chem Toxicol. 2010:48:2913-9.

23. Thangam $R$, Sathuvan M, Poongodi A, Suresh V, Pazhanichamy $K$, Sivasubramanian S, Kanipandian N, Ganesan N, Rengasamy R, Thirumurugan $R$, Kannan S. Activation of intrinsic apoptotic signaling pathway in cancer cells by Cymbopogon citratus polysaccharide fractions. Carbohyd Polym. 2014:107:138-50.

24. Bradford M. A rapid and sensitive method for quantification of microgram quantities of protein utilizing the principles of protein dye binding. Anal Biochem. 1976;72:248-50.

25. Dubois M, Gilles KA, Hamilton JK, Rebers PA, Smith F. Calorimetric method for determination of sugar and related substances. Anal Chem. 1956;28:350-6.

26. Mosmann T. Rapid colorimetric assay for cellular growth and survival: application to proliferation and cytotoxicity assays. J Immunol Meth. 1983; 65:55-63.

27. Cheenpracha S, Park EJ, Rostama B, Pezzuto JM, Chang LC. Inhibition of nitric oxide (NO) production in lipopolysaccharide (LPS)-activated murine macrophage RAW 264.7 cells by the norsesterterpene peroxide, Epimuqubilin a. Mar Drugs. 2010;8:429-37.

28. Eruslanov E, Kusmartsev S. Identification of ROS using oxidized DCFDA and flow-cytometry. Advanced Protocols in Oxidative Stress II Meth Mol Biol. 2010:594:57-72.

29. Kilani-Jaziri S, Mokdad-Bzeouich I, Krifa M, Nasr N, Ghedira K, Chekir-Ghedira L. Immunomodulatory and cellular anti-oxidant activities of caffeic, ferulic, and p-coumaric phenolic acids: a structure-activity relationship study. Drug Chem Toxicol. 2017;40(4):416-24.

30. Chen $\mathrm{H}$, Zhang M, Qu Z, Xie B. Antioxidant activities of different fractions of polysaccharide conjugates from green tea (Camellia sinensis). Food Chem. 2008:106:559-63.

31. Batista JA, Dias EGN, Brito TV, Prudêncio RS, Silva RO, Ribeiro RA, Souza MHLP, Regina CMP, Feitosa JPA, Chaves LS, Melo MRS, Freitas ALP, Medeiros JVR, Barbosa ALR. Polysaccharide isolated from Agardhiella ramosissima: chemical structure and anti-inflammation activity. Carbohy Polym. 2014:99:59-67.

32. Benjamini E, Coico R, Sunshine G. Immunology - a short course. 4th ed. New York: Wiley; 2000

33. Hua X, Chen P, Fox A, Myers R. Involvement of cytokines in lipopolysaccharide-induced facilitation of CGRP release from capsaicinsensitive nerves in the trachea: studies with interleukin-1b and tumor necrosis factor-a. J Neurosci. 1996;16(15):4742-8.

34. Hur SJ, Choi SY, Lim BO. In vitro anti-inflammatory activity of Russula virescens in the macrophage-like cell line RAW 264.7 activated by lipopolysaccharide. J Nutr Food Sci. 2012;142 https://doi.org/10.4172/2155-9600.1000142

35. Pacheco-Sánchez M, Boutin Y, Angers P, Gosselin A, Tweddell RJ. Inhibitory effect of CDP, a polysaccharide extracted from the mushroom Collybia dryophila, on nitric oxide synthase expression and nitric oxide production in macrophages. Eur J Pharmacol. 2007;555:61-6.

36. Kim O, Murakami A, Nakamura Y, Ohigashi H. Screening of edible Japanese plants for nitric oxide generation inhibitory activities in RAW 264.7 cells. Cancer Lett. 1998;125:199-207.

37. Lu YC, Yeh WC, Ohashi PS. LPS/TLR4 signal transduction pathway. Cytokine. 2008:42(549):145-51.

38. Hur SJ, Choi SY, Lim BO. In Vitro anti-inflammatory activity of Russula virescens in the macrophage like cell line RAW 264.7 activated by lipopolysaccharide. J Nutr Food Sci. 2012;2:142. https://doi.org/10.4172/ 2155-9600.1000142.

39. Baeuerle PA, Baltimore D. NF-kB: ten years after. Cell. 1996;87:13-20.

40. Normark S, Nilsson C, Normark BH, Hornef MW. Persistent infection with helicobacter pylori and the development of gastric cancer. Adv Cancer Res. 2003:99:63-89.

41. Sun Z, He Y, Liang Z, Zhou W, Niu T. Sulfation of $(1 \rightarrow 3) \beta$-D-glucan from the fruiting bodies of Russula virescens and antitumor activities of the modifiers. Carbohydr Polym. 2009;77:628-33.

42. Luhm J, Langenkamp U, Hensel J, Frohn C, Brand JM. Beta-(1 $\rightarrow 3)$-D-glucan modulates DNA binding of nuclear factors kappaB, AT and IL-6 leading to an anti-inflammatory shift of the $\mathrm{LL}-1$ beta/IL-1 receptor antagonist ratio. BMC Immunol. 2006;7:5. 